\title{
SYDENHAM VERSUS NEWTON: THE EDINBURGH FEVER DISPUTE OF THE 1690s BETWEEN ANDREW BROWN AND ARCHIBALD PITCAIRNE
}

\author{
by
}

\author{
ANDREW CUNNINGHAM*
}

THE BATTLE of our title, between Sydenham and Newton in the Edinburgh of the 1690s, was waged in fact at one remove: by the most doughty physician follower of each of these celebrated figures. Both Sydenham's medical method, and the medical implications of Newton's natural philosophy, were highly topical in 1690. Sydenham had published in 1686 what proved to be his last work (for he died in 1689), while Newton's monumental Principia appeared in print in 1687. The fever dispute between their respective Edinburgh followers offers us a singular opportunity to assess the implications for medical theory and practice of each of these revolutionary approaches.

The very fact that we are here dealing with immediate followers who are proselytizing for converts allows us, further, to confront a critical issue in the "transmission" or "influence" of ideas. Why are different individuals attracted to - or "influenced by" different ideas? While it may never be possible to answer this question conclusively, it is the contention of this paper that an answer can be approached only after we have contextualized the individuals concerned to the limits of the available evidence.

The central source for the present dispute - the source in which the ideas in question are presented - is a series of some thirty books and pamphlets issued between 1691 and 1702, which have been endearingly described as a bundle of "dreary unreadable rubbish". ${ }^{1}$ Our concern is only with the first dozen pieces of this rubbish, covering the most important stages of the dispute between the partisans of Sydenham and Newton. (These are listed in the Appendix.)

It is perhaps surprising that this battle was fought out not in London but in Edinburgh - which had never previously witnessed intellectual contention on a medical issue. It had, to put it bluntly, been a sleepy backwater. But the professional context of

\footnotetext{
* Andrew Cunningham, Ph.D., Wellcome Unit for the History of Medicine. Free School Lane, Cambridge CB2 3RF.

My thanks to my colleagues: to Adrian Wilson, whose criticisms at every stage greatly helped me understand and interpret the material; and to John Gabbay for comments on the final draft.

1 John Brown, Horae subsecivae, Edinburgh, Constable, 1858; "Dr Andrew Brown and Sydenham”, pp. 457-469, see p. 464. Other partial (and quite inaccurate) accounts of this dispute are in the Preface to volume I of the Catalogue of the library of the Royal College of Physicians at Edinburgh, compiled by J. Matheson Shaw, Edinburgh, Johnston, 1898; and in W. S. Craig, History of the Royal College of Physicians of Edinburgh, Oxford, Blackwell, 1976, pp. 408-411.
} 


\section{Andrew Cunningham}

medical practice in Edinburgh had been quite transformed in 1681. For in that year a group of physicians had at last managed, after several previous attempts during the century, to create a Royal College of Physicians in Edinburgh (RCPE). This was modelled on the London college which had been founded in 1518. The new college thrust the structure of medical practice in the capital of the kingdom of Scotland firmly into the sixteenth century. Its physician founders had become obsessed with reproducing in Edinburgh the same hierarchical division of practice whose enforcement had created so many problems for the London college. In future, they planned, the Royal College was to be the means of supervising the lower grades of medical practitioner in the cause of improving the standards of medical practice. The physicians in Edinburgh would be at the apex of the pyramid of practitioners, with surgeons below them, and apothecaries at the bottom. Those who suffered most from the creation of this structure were Edinburgh's surgeons, who had for thirty years (to the chagrin of the physicians) been calling themselves Surgeon-Apothecaries, and who had been practising the whole range of medicine, including the physicians' preserve internal medicine. So the creation of the Royal College changed the whole course of medical affairs in Edinburgh. ${ }^{2}$

The creation of the RCPE produced conflict between the new institution and the lesser practitioners. But it also produced the opportunity and occasion for conflict amongst the physicians themselves. At its inception the College contained twenty-one fellows, and another half-dozen physicians became members before 1690. It thus included the great majority of the physicians in Edinburgh; and, meeting together regularly, they became aware - possibly for the first time - of their intellectual differences with each other. They were in contact; and they discovered that they disagreed on central issues of medical theory. In short, the very existence of the new institution raised the question of what medical orthodoxy it should hold and promote. The first struggle for its intellectual leadership continued for more than a decade. The dispute over fevers, with which we are concerned, indirectly gave the occasion for the rift; and for a period in the middle of the 1690s two groups of physicians - like the courts of rival medieval popes - were to dispute the right to constitute the only legitimate version of the College.

These disputes are visible to us because so many phases of them were committed to print, and thereby came into the public domain. The availability of print as the medium was, however, accidental, for it depended in turn on the existence of sufficient printers. Although Edinburgh was the printing centre of Scotland, there were only half-a-dozen printers working there in 1690, and this number was in constant danger of being whittled down in a ruthless campaign of prosecution against rivals being waged by the King's Printer. ${ }^{3}$ The competing printers were thus more than ready to accept contracts to print the physicians' polemics against each other: for every item printed represented to them either a blow to, or a defence of, the monopoly of the

\footnotetext{
2 These issues will be dealt with at length in a book I am currently writing on the origins of the Edinburgh medical school.

${ }^{3}$ See the preface to James Watson. The history of the art of printing. containing an account of it's /sic/ invention and progress in Europe... and a Preface by the publisher to the printers of Scotland, Edinburgh, Watson, 1713
} 


\section{Sydenham versus Newton: the Edinburgh fever dispute of the 1690 s}

King's Printer (the widow of Andrew Anderson). Their survival depended on their accepting such work.

The intellectual peace enjoyed by the Edinburgh physicians was broken by Dr. Andrew Brown, who in 1687-88 introduced into the city Sydenham's new method of curing continual fevers. His behaviour during the ensuing dispute had its roots in his earlier career. Andrew Brown (c. 1640-c. 1720) was a member of the gentry (in Scottish terms, a laird), for his father had in 1629 purchased the estate of Dolphinton, some twenty miles south-west of Edinburgh. In their local area the Browns thus became the dominant family, with the right to hold a baronial court. The family were keen supporters of the Commonwealth imposed in Scotland by Cromwell: after the restoration of Charles II, Brown and his elder brother had to pay considerable sums (600 and 1,200 pounds scots respectively) before they could enjoy the terms of the Act of Indemnity (1662). " Possibly it was in order to pay this "mulct" or fine that Andrew Brown turned to the practice of medicine. Though he possessed no university qualifications (not even a first degree), Brown had no qualms about practising medicine: he simply taught himself. He probably called himself "physician", practising on noble and landed patients in his home locality and in Edinburgh as well. His Edinburgh practice was quite legal; the only thing he could not do there (should he have wanted) was call himself a surgeon or surgeon-apothecary. But the establishment of the Royal College in 1681 changed all this. For, while Dolphinton fell outside the College's jurisdiction, Brown could no longer legally practise medicine in Edinburgh.

It was precisely to prevent unqualified people like Brown from practising as physicians that the Royal College had been established. What the proponents of the College had originally intended was for its licence to practise to be restricted exclusively to those with the degree of M.D. Specifically this would be an M.D. of a continental university, where they had themselves been educated; quite justifiably, they distrusted the standards of the minuscule Scottish medical faculties. In such a scheme someone like Brown would have been quite unable to practise, despite his twenty-odd years of experience and his distinguished clientele. But the combined opposition of the Scottish universities had introduced a major concession into the physicians' charter.' For the College was obliged to license M.D.s of the Scottish universities without any examination at all. This was the only category thus privileged - though even Scottish M.A.s could not be prohibited from practising unless they had first been examined and found wanting. So if Brown wanted to continue practising in Edinburgh his easiest way of doing so was by securing an M.D. from a Scottish university. The university to which he applied in June 1685, King's College, Aberdeen, was more than amenable. King's College had in 1681 opposed the physicians' charter and had stoutly defended the rights of its medical graduates to practise freely, although its most recent M.D. had in fact graduated as long ago as 1673 . Brown was therefore a welcome candidate; moreover, he offered himself for examination. It was, thus, a satisfactory arrangement for both parties. So after formal examination and

\footnotetext{
4 For this biographical information on Brown, see G. V. Irving and A. Murray. Upper ward of Lanarkshire, 3 vols., Glasgow, 1864, vol. 1, pp. 368, 374.

${ }^{3}$ The charter is printed in translation in Craig, op. cit., note I above. pp. 1043-1048.
} 


\section{Andrew Cunningham}

two days of ceremonies, Brown received his patent and returned to practise freely in Edinburgh as Dr. Brown. ${ }^{6}$

During his years of practice Brown had apparently followed some of Sydenham's advice on the treatment of fevers, a subject on which Sydenham had been publishing since 1666. But when he read Sydenham's latest book in 1687, Brown was astonished. For in his Schedula monitoria (1686) Sydenham, Brown found,

delivers as confirmed by manifold experience, not only a new, but a quite contrary method to the common, of curing continual fevers. I did long hesitate, thinking that either he, or all other physicians were in a high delirium like their patients, and were grossly deceived about the cure of fevers. And lest the preconceived opinion I had of the man's ingenuity should so far impose upon my credulity as to draw me into an error likewise with him, and make me experiment that method when I knew not but I might run the hazard to sacrifice some [patients] to my temerity, nothing could settle my tossed thoughts except the sight and knowledge of the thing itself.

Immediately therefore hastening to London, and having met with the man and exposed the occasion of my coming, I found concerning him and his practice all those tokens that usually beget trust and knowledge in wary and prudent people making serious inquiry. Then after some months spent in their society, returning home as much overjoyed as I had gotten a treasure, I immediately set myself to that practice.'

The occasion for Brown revealing all this arose from the fact that when he began to practise Sydenham's method in continual fevers, other physicians began to attack his reputation and skill. After a long series of what he claimed as successes in using the treatment, including on his own family, Brown committed the mistake of trying it on a member of the nobility, Lord Creichton. The patient died under the cure. ${ }^{8}$ This was enough to damn Brown and his method in the eyes of other Edinburgh physicians, and it gave them a handle on which to hang their abusive gossip. So Brown decided to publish a full vindication of himself, of the method, and of his treatment of Lord Creichton. This is the Vindicatory schedule of 1691 - the first shot fired in the Edinburgh fevers dispute.

Such were the circumstances which we can call the preconditions for the visible emergence of the fever dispute. Before exploring it, we must first establish the contemporary technical vocabulary, and define the prevailing method of treatment applied to fevers in Edinburgh before conflict arose. Second, in turning to the dispute itself, we shall consider in turn the introduction to Edinburgh of Sydenham's method; the general reaction to this among the Edinburgh physicians; and the Newtonian counterblast which followed. Third, it is appropriate to set the dispute in its political context, which was intimately connected with the medical issues. Finally, we shall see that the dispute was to be significant for the RCPE itself: the institution whose existence had in some sort precipitated the conflict was not to remain unscathed by it.

\footnotetext{
'Full details of Brown's examination are given from the records of King's College in P. J. Anderson (editor), Officers and graduates of King's College, Aberdeen, New Spalding Club Publications, 1893, no. 2. pp. 120-122.

'Vindicatory' schedule (no. 1 in Appendix below). Preface. The passage has been modified here in the interests of readability, and the spelling modernized.

' Lord Creichton is probably Charles, Lord Crichton, son of the second Earl of Dumfries. Born c. 1645 , he married a daughter of Lord Stair in 1679 and had four daughters, as well as a son who became the third Earl. Charles died before his father, and is buried at Dumfries. His date of burial (11 March, 1690) and his relationship to Lord Stair, make it probable he was the patient whom Brown treated. See The Scots Peerage, 9 vols., Edinburgh, Douglas, 1904-1914, vol. 3, pp. 235-236.
} 


\section{Sydenham versus Newton: the Edinburgh fever dispute of the 1690s}

Although the dispute was to be bitter and protracted, its protagonists shared a common framework of concepts and terms; and it is necessary to begin by explaining this framework, which was drawn from the classical bases of medicine. Most basic of all is the idea that nature has a "natural" way of responding to any disease, and tries to eliminate the offensive matter (whatever it is) through suitable natural pathways of the body. It was the physician's duty to discover the stages and timing of this natural process which consisted of the "concoction" (preparation) and then the elimination of the offensive matter. Then it was his duty, where necessary, to assist the process to a happy conclusion. For the unassisted process did not always work; this, after all, is why patients died. The proper secretions or evacuations might be suppressed, for instance, or the body might be too weak to effect the necessary stages of concoction. Two Hippocratic aphorisms were regularly called on in this respect: section one number 21 , teaching that matters to be evacuated should be evacuated in the direction to which they tend; and number 22 , teaching that matters to be evacuated should no doubt be evacuated at the onset of the disease, but only when they have been concocted in the body. The signs that this concoction has taken place can be found in changes of colour and consistency in the urine or stools. Thus far everyone agreed on the general methodological principle that nature's pattern in overcoming disease should be followed and assisted. Similarly, the rival methods agreed on certain technical concepts and terms to refer to the various levels of the physician's intervention (mostly taken from Galen). The physician's aim is to remove the true cause of the disease, where possible. The true cause, however, can be identified only by interpreting various signs and indications, which give information about different levels of cause. Galenic medicine distinguished four such levels of cause. There were predisposing causes, such as the patient's personal constitution, the season of the year, and the weather. Then there were external ("procatarctic") causes, generally collected under the heading of the six "non-naturals": the air, food and drink, sleep and watch, inanition and repletion, exercise and rest, and the state of the mind. These, if not in due proportion or relation to each other, would bring about undesirable physical changes in the body, and these physical changes were the antecedent causes - such as an obstruction somewhere, a suppression of normal excretion, the creation of unhealthy chyle in the stomach, and the like. Finally, we come to the immediate (or "continent") causes: and there was general agreement that, in the case of fevers, the immediate cause was some unnatural state or behaviour of the blood. It was this that the body was trying to resolve, trying to concoct the blood into a healthy state again. Therefore, when a fever had a good outcome it was because the concoction had taken place and the troublesome matter had been expelled through an appropriate exit, all at appropriate and proper stages.

The Edinburgh doctors, trained in these classical approaches, had evolved a generally agreed method in treating continued fevers, which can be outlined as follows. ${ }^{9}$ Fever was diagnosed from a combination of such symptoms as headache, a feeling of coldness, lassitude, frequent pulse, "red and thick" urine, thirst, loss of appetite, heat, and inability to sleep. The physician next looked at the patient's con-

\footnotetext{
9 This account relies on Forrest (Appendix, no. 7). This is, of course, an interested account, and there may not have been a single agreed therapy being practised in Edinburgh.
} 


\section{Andrew Cunningham}

stitution, his age, strength and the like: according to the assessment made of these factors, the details of the treatment were to be suitably modified to suit the patient's condition. As a fever had been diagnosed, so it was known that the "immediate" cause was a certain disturbance of the blood. Removing the disease therefore meant allaying the disturbance by expelling whatever in the blood was causing the disturbance (i.e. the "antecedent" cause). The first operation was to bleed the patient: the full rationale for this is not known, but it may be assumed that by thus reducing the quantity of affected blood the body was being given a better chance in its fight to resolve the blood which remained. Bleeding also had the visible effect of reducing the pulse and seeming to soothe the symptoms generally. Then, as the antecedent cause was usually judged to be some ingested matter likely to continue to be moved into the blood and sustain its febrile condition, the patient was vomited to empty the stomach. If both bleeding and vomiting were required, it was essential that they be administered in that order lest "by the shaking of the body" during the vomit, "some small vessel should burst". Next it was necessary to assist the process of concoction by giving inciders-medicines believed to have sharp particles which would cut up and render the offending fluid less viscous; this, with the administration of gentle purges (aperients) continued until the urine revealed that the process of "separation" had begun. Finally, the physician turned to nature's own way of eliminating the peccant matter. Nature uses sweats, so a diaphoretic should be administered, which was called "the universal cure of fevers, Nature pointing with its finger to their use". In this way a crisis had been artificially brought on, the physician thus helping nature wrestle with the disease. This, then, is the simplified structure and framework of the usual way of treating continual fevers. To summarize, its components were (and the order is crucial): (1) bleeding; (2) vomiting; (3) inciders; (4) sweating.

Brown's therapeutic procedure was radically different. In essentials it consisted of: (1) bleeding; (2) purging; (3) paregoric (a "quietener"). The purging and quieting were repeated in turns, until the fever had quite abated. The fact that an initial bleeding was common to both approaches is a trivial level of agreement between them. The defenders of the old method saw sweats as the very heart of treatment: it was nature's own way of eliminating the concocted matter. Brown's therapy, on the other hand, contained neither a medicine to promote the concoction of the blood, nor any means of eliminating the concocted matter through the pores of the skin! Thus at the practical level, this new method was certainly (as Brown himself had recognized) "quite contrary to the common".

It may be of value here to use an illustration that Brown himself provided, his manner of treating Lord Creichton. The chief symptom of the continual fever of this patient was great difficulty in breathing. Brown came to him first on the sixteenth day of the fever, when asthmatic paroxysms were alternating with deliriums. These symptoms indicated to Brown that the morbific matter was moving around the patient's body (in the blood); the chief danger was that it would return to the lungs after the delirium. Hence the matter needed urgently to be evacuated as much as possible by bleeding. The patient was judged strong enough for this to be of benefit, and his urine showed the initial signs of the morbific matter being concocted in the blood. The next stage of Brown's treatment was to administer a relatively gentle purge: and the breathlessness 


\section{Sydenham versus Newton: the Edinburgh fever dispute of the $1690 \mathrm{~s}$}

and fever were much abated. The purge was continued throughout the next day. Here Brown was faced with a typical decision calling on his judgment as a physician. If the cure (the purge) were continued, the patient would lose strength; yet if his strength were preserved (by restricting the looseness of the bowels), then the cure might be jeopardized by the return of the morbific matter to the lungs. So Brown administered small doses of the paregoric - "with which method through the whole course of the disease he was treated, giving more or less vent to his belly by the counsel of the more pressing indications, and that by the use or abstinence of the paregoric". Brown the physician, thus used his skill to alternate well-judged doses of the purge and the paregoric, gradually purging the morbific matter from the intestines while keeping the patient strong enough to profit from the cure. This was the new method. In Lord Creichton's case, unfortunately, it "could only" (in Brown's words) "prolong his life for eight days", and on the twenty-fourth day the morbific matter suddenly fell again on the lungs causing high and vehement breathing, and the patient died. The post mortem proved that the lungs were full of a viscid phlegm.

Insofar as we can judge from the symptoms Brown described, the illness of Lord Creichton conformed well to the continual fever dealt with by Sydenham in his Schedula monitoria, and which broke out throughout England from February 1685. Sydenham had thought it resembled a kind of peripneumony, where the disease constantly threatened to concentrate around the lungs, and he treated it accordingly. ${ }^{10} \mathrm{All}$ Sydenham's treatments seem to have been assembled in this manner: trying something which had worked in a previous fever which he thought the present one resembled. Then a process of trial and error was used to modify or correct the treatment, until a series of successful recoveries proved it to be correct. Thus did the individual and distinctive disease find its individual and distinctive mode of treatment. This method had led to the bleed-purge-paregoric sequence in the continual fever presented in the Schedula monitoria, and which Brown was now practising in Edinburgh. The very cornerstone of Sydenham's "method" was this experiential basis: to Sydenham it was a major virtue that the cure was found by confronting disease by skilled trial and error, rather than by working from within a theoretical understanding of physiology and pathology. Indeed, Sydenham professed it to be the only valid approach, and he repeatedly condemned in print other physicians who failed to abandon their theories.

This rhetoric Brown too adopted in the first part of the Vindicatory schedule, including the impassioned attacks on theorizers. He also elaborated the physician's task as a servant of nature: likening him to the wily and prudent servant of an irascible human master, who could observe the regularities in the moods of his master and eventually was able not only "to perform his master pleasant and profitable service, but calming his severities, moderating and governing him, may exercise a kind of dominion over him"." To this end the proper physician should keep a journal of his practice and treatments:

\footnotetext{
10 Thomas Sydenham, Schedula monitoria de novae febris ingressu, London, 1686. The best translation is still probably that by John Pechey, The whole works of that excellent practical physician Dr Thomas Sydenham, London, Wellington, 1696; (2nd ed., 1697); 3rd ed., 1701, pp. 410-453.

1 Vindicatory schedule, pp. 45-46.
} 


\section{Andrew Cunningham}

And moreover, this journal serving the physician for a map of the various uniformity of the operations of nature, and these even by his own survey drawn from the life, the serious and frequent view thereof (by giving him more solid, full and bright ideas of diseases and their cures) only begets that so much talked of (but rarely found) experimental knowledge, which in proportion to its solidity will surely direct the steady steering of his course in after practice. And that the solid experience in medicine (though after never so much practice) can noways so fully and exactly be produced as by such an exact historiography, is altogether clear from the multiplicity, complexity, inveiglement, and variety medical cases are always circumstanced with. ${ }^{12}$

This particular interpretation of what "experimental knowledge" should mean for the physician was one of the most striking lessons learnt by Brown from Sydenham.

Yet Brown was not another Sydenham, nor even a neutral mouthpiece for the virtues of the treatment he had personally learnt from the master. Consequently, the Vindicatory schedule was far more than a defence of Sydenham's methods in Sydenham's own terms. Brown told us (as we have already seen) that when he first read Sydenham's Schedula monitoria he had been totally perplexed, and long hesitated to adopt the method. So he went to London to see for himself. As a result of what he saw of Sydenham's own practice of the method, Brown concluded that it was correct, and superior to the traditional management of continual fevers. It may be because he had been self-educated in medicine that Brown was prepared to accept - if he could see it demonstrated - that a method found by trial and error might work, even though it was quite contrary to the usual method. But the success of the new method gave Brown a fresh dilemma. How could it be that the theory of Sydenham worked at all? For reason was against it. Sydenham had been able to make a virtue of the fact that his approach renounced the use of physiological categories for its comprehension. But for Brown this renunciation was not so easy: for in his self-education it had been the mechanical philosophy that he had learned, and for a quarter of a century he had been relating to this philosophy his whole medical practice. He was not, therefore, willing to follow Sydenham in attempting to abandon all explanatory categories. Possibly this was because, unlike Sydenham, he did not have a John Locke at his elbow to buttress this position with philosophical arguments; possibly he could not grasp the full meaning of Sydenham's views. At all events, he now set himself the task of understanding how it was that Sydenham's treatment worked - and, axiomatically, this meant understanding it in mechanistic terms. He duly puzzled over it and reached at least a preliminary answer, published in the Vindicatory schedule. He claimed that he was in fact prepared to learn that the precise interpretation he had developed might be in error; but even if it were to be proved fallacious, Brown had solved his own problem. For he had satisfied himself that an explanation could in principle be found: that Experience stood confirmed by Reason, and was not antithetical to it. It might seem to us at first sight that Brown was engaged in the paradoxical enterprise of defending in one manner a form of treatment which had actually been found by a quite different type of approach. To our eyes the project should be doomed. Yet seen in the light of Brown's own standards of what comprised an adequate understanding of medical phenomena, the marriage of Sydenham's treatment and Descartes' theory was not ill-matched.

12 Ibid., p. 24. 


\section{Sydenham versus Newton: the Edinburgh fever dispute of the 1690s}

Brown's theoretical explanation opened with a declaration of adherence to Cartesian physiology: "the animal oeconomy is founded in a mechanic structure, to wit in matter and motion". The body could be looked on as a machine; when in good order it is in what we call health, and when some mechanical problem occurs in it, we have states of "disease". The differences between diseases arise from differences in the site of the defect, or in the particular combination of defects: hence "the multitude of diseases is begotten". Yet beneath this multiplicity of ways in which the defects show themselves there lies a simple structure - and this belief in the underlying simplicity of the invisible mechanical structure was essential to all "mechanistic" explanations of body functioning. In sharp distinction to Galenic medicine with its host of separate "faculties" and "powers", mechanistic medicine used as few explanatory categories as possible; ideally the number of categories was reduced to two - matter and motion. ${ }^{13}$ So its explanations were couched in terms of particles (the matter) moving with respect to, or colliding with, other particles massed together as the structures of the body. The mechanistic approach had also absorbed Harvey's discovery of the circulation of the blood, and therefore the particles making up the fluids of the body were seen as flowing around through their appropriate channels, whose walls were constructed (as were the organs of the body) of sets of tiny hollow fibres made of chains of particles.

The paradigm explanation in Cartesian physiology was that of secretion through glands. In this the different particles which, mixed together, make up the blood, are regarded as having an "intestine" (i.e. internal) motion with respect to each other; or, in other words, they behave as this particular fluid. The blood flows and meets a gland; the gland is built of other particles massed together into a certain distinctive structure. Where the blood meets the gland, the surface of the gland is structured like a sieve, with holes of particular shapes and sizes. Only those component particles of the blood with shapes and sizes exactly corresponding to these holes will pass through. The whole process is passive: the particles are separated off simply because of their size and shape, not because of their quality or the properties of the material of which they are composed. The particles thus secreted, still having intestine motion with respect to each other, now comprise a different distinctive fluid. This fluid will show perceptible secondary qualities (such as taste and colour), but it is the primary qualities alone of the particles (shape, size and motion) which are responsible for the distinctive properties of the new fluid.

As far as we can judge, this Cartesian approach (as developed by Malpighi, Borelli, and others) was the dominant form of physiological explanation at this period, and was thus shared by the Edinburgh medical community. It was very exciting, constantly being developed by incorporating fresh anatomical discoveries, while it also prompted investigations to reveal hitherto unsuspected functional parts of the body. Dr. Dominique Beddevole, whose Essays of anatomy were reprinted in translation from the French by one of the tiny band of Edinburgh printers in the very year in which Brown was writing, caught this excitement very well - while dragging an unwill-

\footnotetext{
${ }^{13}$ This account of Cartesian mechanism draws heavily on T. M. Brown, 'The mechanical philosophy and the 'animal oeconomy': a study in the development of English physiology in the seventeenth and early eighteenth century', Princeton University unpublished Ph.D. thesis, 1968.
} 


\section{Andrew Cunningham}

ing Harvey into his list of those who had been inspired by Descartes:

Thanks to the penetration of an excellent philosopher of this age, it has been discovered that the living body is nothing but a machine. Men have applied their minds to discover its springs. In this Harvey and Pecquet have been successful.... Their example has animated all anatomists. They found they had made small progress in the knowledge of this machine. They were persuaded that they needed but to search to make discoveries. In effect the Bartolins, the Whartons, the Stenos, the Willises, the Lowers, the de Graafs etc. and above all the Malpighis have searched very deep into the structure of the living body. The discoveries which they have made do give us an idea of an animal altogether different from what the ancients had of it. ${ }^{14}$

For Brown's purposes these physiological principles had to be applied to the sphere of pathology. Disease was now understood as being due ultimately to some defect either in these fluids or in the vessels and organs in and through which they flowed. In Brown's account, such defects in the vessels or organs resulted from their hollow constitutive fibres becoming filled with thick fluids ("gross humours"), thus becoming too rigid and hence hindering or completely stopping the flow of the fluids there. Defects in the fluids themselves consisted of adverse changes in the intestine motions of the fluid's particles, brought about through the inclusion of some undesirable particles; these unwelcome particles came either from a failure of proper digestion in the stomach, or from a failure to expel "excrementitious" particles (such as perspiration) at their natural time. Defects in the fluids and the vessels reacted on one another, a fault in the one therefore giving rise to a fault in the other. When Brown turned to giving his mechanical account of continual fevers, these were the categories within which he worked, and thus far no mechanist would have disagreed with him, for his exposition was typical.

But Brown was facing a new problem, one not hitherto addressed by Cartesian theorists. He had to find a formulation to justify two things: first, Sydenham's neglect of sweating in his therapy for continual fever; and second, Sydenham's concentration in his therapy on the antecedent cause (rather than on the immediate cause in the blood). Brown solved this problem as follows. In health the heart propels the blood around the body in order to repair the tissues which are perpetually being worn away through attrition by the action of the muscles. The worn and used particles go off as insensible perspiration through the skin, helped on their way by the volatility of the air particles which have entered the blood via the lungs. But if for some (unspecified) reason this insensible perspiration is retained, major disturbances follow. The used particles accumulate; the body tries an emergency evacuation of them through a sweat, i.e. a sensible, or detectable, episode of perspiration. If this is unsuccessful, the particles continue to accumulate in the blood and act as a "gross humour". They either fill the vessel-fibres and make them more rigid, or they render the blood thicker by their presence and thence make the natural particles of the blood misshapen. At all events, the practical result is that the blood slows down or even stops in places. Yet there is a self-clearing mechanism which can operate here, Brown claimed. The

\footnotetext{
${ }_{14}$ [Dominique Beddevole], Essayes of anatomy, in which the construction of the organs and their mechanical operations are clearly explained, according to the new hypotheses. By ******** Dr. of Medicine. Written originally in French, Edinburgh, Mosman, 1691. This is a pirated reprint of the London edition of 1691, translated by J. Scougall. The French original was published in 1686. A further edition of the English translation was published in London in 1696.
} 


\section{Sydenham versus Newton: the Edinburgh fever dispute of the $1690 \mathrm{~s}$}

particles of the blood in this condition rebound against the nerves (like reflecting and refracting rays of light); this accounts for the sensations of heat and pain. This commotion at the nerve-ends is registered in the brain, where a greater supply of "animal spirits" is put down the nerves controlling the heart. The heart therefore beats faster. That is, the increased heart-beat is a mechanical reaction to overcome a blockage in the blood-stream. It is thus, Brown considered, the slowness of the blood which is the immediate cause of continual fevers - not, as was the conventional view, the rapidity of its flow. Most fevers will now be cleared: the stronger impulse of the blood clears out the blockage and restores normal flow, while it also knocks the misshapen particles back into shape. (Brown does not tell us, but presumably the pores also go back to their proper shape, and the excrementitious particles which had caused the trouble get cleared by insensible perspiration.) Brown has thus shown convulsions, hysteric affections, and the like to be side-effects of the blockage or of the natural attempt to clear it, caused by "collisions" of particles on nerves. Similarly, he has shown that all the things which are normally thought to be symptoms of a fever (such as heat, pain, rapid pulse, sweats) are in fact stages of the natural cure; in this he was true to Sydenham's view.

Most fevers cure themselves. A proportion, however, do not, and in these the physician must intervene. The worst such cases are continual fevers. In these the body is continually working to clear the blockage in the blood-flow, but it can never succeed. The reason is - and this is the only noticeable logical jump in Brown's explanation - that crude (or "undigested") particles keep entering the blood from the intestines and keep it clogged up. They are crude because (for some unexplained reason) the fever has reduced the efficiency of the patient's digestion. The morbid condition in continual fevers was thus, in Brown's view, self-perpetuating: this is why they are continual. But if this supply of fuel for the disease were to be cut off, then (Brown reasoned) the body will be able to clear the obstruction itself, and return to a state of health. Hence the physician's attack must concentrate on this supply: purging must, of course, be the main therapy. To prevent the purge by its violence from sending fresh morbific matter into the blood and thence into the nerves, the other measures are necessary: "the inconvenience and tumult arising from the irritation of the purgative is very efficaciously restrained by the immediately preceding phlebotomy and the subsequent use of the paregoric". In the light of this picture of the mechanics of continual fever, Brown then discussed at length the other details of Sydenham's therapy and advice, and dismissed the therapeutic measures used by other practitioners. The therapy that Sydenham had learnt from trial and error in practice had now been justified by the rational arguments of Cartesian mechanism. Reason had been used to demonstrate why it is the antecedent cause and not the immediate cause which must be treated in continual fevers. Reason and experience thus go together, hand in hand.

None of Brown's views in the Vindicatory schedule was put forward with any spirit of apology. His book was very much on the offensive, including as it did unsolicited advice on how the physicians of the RCPE ought to behave. One reason for Brown's aggressive confidence may lie in another area: for he took great care to convey to his readers his political position. Brown proudly announced that he was (what we would 


\section{Andrew Cunningham}

call) a whig. Here it must be noticed that this dispute over fevers broke out in times charged with political significance. In December 1688 James VII and II fled his thrones, and William and Mary were invited to succeed him. Though the new monarchs were proclaimed separately as rulers of England (February 1689) and Scotland (March), the political complexion of those who engineered the change in the two countries was the same. Both Conventions were dominated by "whigs" - those who had regarded James's rule as "tyranny" and "oppression", and who claimed that under such circumstances it was the duty of the citizenry to resist, and even go as far as to replace the monarch. Hence the invitations to William and Mary to accept the crowns on certain conditions. But the activists of 1688-89 embraced a wide spectrum of belief, and in the wake of this "Glorious Whig Revolution", differences in the whig camp began to appear. For this audacious constitutional experiment required justification to themselves and others, by those who had been its principal actors. To oversimplify, one may point to two main whig positions. First, there was a "moderate" position: the conditions under James had been so exceptional as to justify desperate expedients. But now he had been replaced, the new monarchy should be respected, and law and order should prevail. Second, and in violent contrast, there was an "extremist" position, whose advocates held that the 1688-89 revolution was in need of no special justification, for it was the citizen's duty always to oppose tyranny. The new monarchy might equally well succumb to the temptation to tyrannize; the citizenry reserved the right to depose it in turn, and to replace it with perhaps a quite different form of government. So (in this view) the revolution of 1689 was far from being the last word in constitutional experiment. This is what is sometimes called the "commonwealth" or "patriotic" position in Scotland, and its best-known advocate was Andrew Fletcher of Saltoun. ${ }^{15}$ So in the years immediately after 1689 both wings of the whig grouping felt compelled to produce post factum justifications first of the legitimacy of the revolution itself, and second of their subsequent attitude towards the new monarchy.

It is necessary to be cautious in categorizing people politically immediately after 1689 , for it was obviously expedient to declare whig sympathies if one wanted jobs and patronage. It was also very ill-advised to declare oneself a supporter of the deposed monarch (i.e. a Jacobite), for this was now potentially treasonous. But we can recognize Brown's genuine political position with some confidence. Years before, as we have seen, he had been fined for supporting an anti-monarchical position. A decade after the present fever dispute he was publishing political works which reveal that he held a "patriotic", extreme whig, position. So the political position he declared in the Vindicatory schedule can be taken at its face value. The choice of dedicatee is significant too: James Dalrymple (Lord Stair), who had been in political exile in Holland, and on returning with William of Orange had been appointed Lord President of the Court of Session. Stair was an excellent choice of patron on several grounds - a man of learning, father of a physician, Brown's connexion with the late Lord

\footnotetext{
15 There is no adequate modern account of Fletcher or of the patriotic Whig position in Scotland. But for some useful discussion see J. G. A. Pocock, 'Machiavelli, Harrington, and English political ideologies in the eighteenth century', William and Mary Quarterly, 3rd series, 1965 22: 549-583; reprinted in his Politics. language and time, London, Methuen, 1972.
} 


\section{Sydenham versus Newton: the Edinburgh fever dispute of the $1690 \mathrm{~s}$}

Creichton (Stair's son-in-law), and apparently himself a patient of Brown's. ${ }^{16}$ But what Brown was most concerned to stress was Stair's connexion with "that Heroic Prince (now our Sovereign)", the Prince of Orange. In so doing Brown affirmed that he was a Whig - and proud of it.

Brown's patriotic whig position went further than just insisting on constitutional arrangements which would reduce the chance of tyranny occurring. These patriots regarded the positive promotion of the public good to be their duty too: for Scotland to flourish, the landed gentry must take the initiative. Any scheme which might help the independent nation to flourish should be seriously considered. In 1705 Brown was to urge that a Council of Trade be created, and a land-bank be established to issue a paper currency. ${ }^{17}$ This highly innovative approach was not limited to Brown's political writings. He also advocated a specitic project to promote the kind of medicine he believed in. He mentioned in 1692 a plan he had to set up "within the Kingdom a Profession [i.e. teaching] of Medicine, with Hospitals for the Sick, subservient thereto". He looked to Lord Stair to patronize the project and thus "in that affair discharge the Office of a true Patriot of his Country". ${ }^{18}$ The scheme was probably intended to be self-financing in some way. The mention of a hospital to be associated with medical teaching recalls Sydenham's obsession with learning medicine at the bedside. It was from the vantage-point of this active, projecting, whig position that Brown saw his physician opponents as enemies of the good of Scotland and the health of the populace. He used terms with a very specific political meaning with which to condemn them: "they do thereby most severely and successfully tyrannize over improvements, and their advancers: in regard they are jealous such improvements come to supplant them, and to steal away their Gods of Profit and Esteem". ${ }^{19}$

Certainly there seems to be a considerable correspondence between the political position of Sydenham the master and Brown the pupil. For Sydenham had fought in the Parliamentary army during the Civil War; and it is quite likely that he would therefore have assumed a similar whig attitude to the events of 1689 (had he lived). So we may assume a strong political sympathy between Sydenham and Brown - even if in fact they only discussed medical matters - when they met in the penultimate year of James's reign. Furthermore, if the above brief characterization of the extreme whig position is accepted, there are a number of further correspondences between Brown's medicine and his politics which can be made. It was, Brown repeatedly asserted, the very survival and well-being of the patient that was at issue in medical treatment: if this could be secured only by unorthodox procedures which did not have the sanction of custom or ancient authority, then the unorthodox remedies must be adopted, and the custom or ancient authority be rejected. Similarly, the whig attitude was that in

\footnotetext{
${ }^{16}$ On Stair see Dictionary of national biography. While in exile, Stair had published Physiologia nova experimentalis, Leyden, Boutestyn, 1686 - a massive reconciliation of the physics of Aristotle, Epicurus, and Descartes. His physician son was Thomas Dalrymple. On Stair's role in introducing Brown to Creichton, see Appendix, no. 2.

${ }^{17}$ An essay on the new project for a land-mint, Edinburgh, 1705. A second essay on the land-mint, Edinburgh, Symson, 1705.

18 See appendix, no. 5, pp. 41-42.

19 Ibid., p. 4.
} 


\section{Andrew Cunningham}

making decisions and taking actions about types of government, it was the very survival of the nation which was at stake: unorthodox constitutional procedures should be adopted if they were the only means by which the survival of the nation could be secured. As we have seen, Sydenham devised his therapeutic sequence in continued fevers by trying expedients to see what would work. For a whig like Brown, we can infer that the same method was applicable in the state: experiments should be tried to see what actually worked, even if it meant adopting a succession of different approaches. If it was required, one could relate the effectual procedure to its necessary theoretical base - after the event. As Brown wrote, about medicine, "it's only solid and sound practice that must yield a true theory". ${ }^{20}$

But this is not all. For, at several places in the Vindicatory schedule Brown explicitly developed a parallel between medicine and politics, claiming that revolutions against tyranny and oppression are natural and desirable responses to obstructions in the body politic, in just the same way as fevers are natural and desirable responses which will clear obstructions in the body natural.

Different effects from the like occasional cause in the natural body, are paralleled by the like different consequences springing from the same occasional causes in the body politic. So Tyranny and arbitrary government exercised upon a heroic and generous-spirited people, uses to beget war; but all the impression it makes on a servile and despirited nation, resolves only in languishing and depopulation. And the parallel may be carried yet further, for as tyranny and oppression of a people is often shaken off by civil wars, and they thereby brought into a vegete and flourishing state; so chronic distempers in the natural body are often loosed by a supervening fever, and the body thereby is brought into a sound and healthy condition. ${ }^{21}$

These parallels were used again in Brown's later, overtly political, writings. ${ }^{22}$ Thus Brown was making a striking effort to equate good medicine with good whiggism.

In publishing the Vindicatory schedule Brown had brought the whole topic into the public arena, where it might be read by potential patients and patrons. He had written his book in a way which turned the attack on his physician opponents, accusing them of insufficiency and arrogance. He was challenging the practice of the members of the very institution established to defend and promote good practice in Edinburgh: the College's legitimacy was under attack. Within the College the pursuit of illegal practitioners was the duty of the two Censors. In 1690-91 one of these Censors was Dr. Pitcairne. ${ }^{23}$ Unfortunately for the College, Brown could not be prosecuted, for he now possessed an Aberdeen degree. The only way to meet his challenge was to adopt

\footnotetext{
${ }^{20}$ Vindicatory schedule, p. 64.

${ }^{21}$ Ibid., pp. 187-188.

${ }^{22}$ See note 17 above; Brown's other political writings are The character of the true public spirit. [Edinburgh], 1702; Some very weighty . . considerations . . for a union of confederacy . . . [Edinburgh], 1703; $A$ scheme, proposing a true touch-stone for the due trial of a proper union betwixt Scotland and England, Edinburgh, Symson, 1706. The Bibliotheca Britannica (edited by R. Watt, Edinburgh, Constable, 1824) credits Brown with two further works of which no trace can be found: Motive of cold baths; with an advice respecting water drinking, London, 1707; and Institutions of Physick, London, 1714: these are probably ghosts.

${ }^{23}$ The minutes of the RCPE are missing for this period. But it is known that Pitcairne and Sir Archibald Stevenson were Censors at this time: see the dedication to them of Charles Maitland's Leyden thesis of 18 May 1690.
} 


\section{Sydenham versus Newton: the Edinburgh fever dispute of the $1690 \mathrm{~s}$}

his own technique, and to seek to humiliate him, in turn, in front of the reading public. So a group of collegiate physicians, led by Archibald Pitcairne (1652-1713), published a reply to Brown, using the subtle pseudonym of "Dr. Black". Brown (in no doubt as to their identity) printed in reply a number of Letters in his own defence, using the pseudonym Philander (Lover of Mankind). ${ }^{24}$ Eventually, Brown forced the physicians to produce a reply which went beyond smear tactics and actually engaged with his medical arguments. This reply, which appeared in 1694, was written by the young physician, James Forrest. Entitled $A$ brief defence of the old and successful method of curing continual fevers, this amplified and reiterated features of "Dr. Black's" pamphlets, and is the most convenient text through which we may assess the grounds on which Brown was rebuked.

Forrest was the very epitome of a conventional, university-trained physician. In his medical education at Leipzig, Danzig, and Leyden, ${ }^{25}$ he had been taught - in the normal way - not clinically, but in lectures and from books. As a result, he had learned to see the very course of fever through the categories of a particular interpretation - one which was conventionally mechanistic. This meant that Forrest's Brief defence used a similar vocabulary to the theoretical part of Brown's Vindicatory schedule. But there the resemblance ended. For the self-educated Brown, the theory played the part of an explanation post hoc; Forrest's education, on the other hand, would have made it inevitable that he should see theory as the very basis of rational therapy. It is hardly surprising, then, that Forrest found Brown's approach both erroneous and distasteful. His Brief defence sought to refute the errors and to give vent to his contempt.

Forrest thought that the immediate cause of all fevers was the presence of unwelcome particles in the blood, disturbing its proper intestine motion; therapy should aim at the expulsion of these particles. When he looked at the "new" method being advocated by Brown, he found these fundamental matters being quite misunderstood. In the first place, Forrest had been taught that a whole variety of different factors (such as misuse of the non-naturals) could introduce such unwelcome particles into the blood. But he found Brown maintaining that the blood could be disturbed in this manner by only one antecedent cause (obstruction of the blood-vessels from the suppression of insensible perspiration) - a grotesque oversimplification. Second, he found Brown teaching that the stomach and intestines had to be cleared by purging throughout continued fevers - again an obvious error. In Forrest's eyes this betrayed a complete misunderstanding on Brown's part of the difference between intermittent and continued fevers. In intermittent fevers the morbific matter in the blood is intermittently being renewed by fresh supplies from the stomach and intestines - this is obvious from the symptoms - whereas in continued fevers the phenomena show that the morbific matter has already arrived in the blood. Hence in intermittents the physician must clear the stomach and intestines; but in continuous fevers clearing the

\footnotetext{
${ }^{24}$ See Appendix, nos. 3, 5 and 6. Another pseudonym Brown uses for himself in no. 5 is "Philarchus" (Lover of Rule), which might possibly be intended to convey the sense of "loyal to the government".

2s I have inferred his educational tour from his dedications to his 1691 Leyden thesis, De mensibus vitiosis. In 1694 Forrest was not yet a member of the RCPE - possibly because he was practising outside the town; later he was to rise to the position of President.
} 


\section{Andrew Cunningham}

stomach and intestines is a waste of time, because the morbific matter has already been transferred to the blood! The "new" treatment was thus not a cure at all to Forrest's understanding as it failed even to try to remove the immediate cause. It was mistaken, useless, and probably dangerous. It was impossible that the "new" therapy could be the successful cure, because it was totally irrational.

In these ways Brown revealed himself in Forrest's eyes as someone who just did not know what he was doing. His understanding of medicine was defective, and his education must ipso facto have been quite inadequate - no matter how long he had been in practice. But Brown had aroused the real ire of physicians like Forrest not just because of these technical deficiencies, serious as they were. For they were just one aspect of his opinions and behaviour, all of which Forrest condemned in a revealing phrase as "most false, ridiculous and dishonourable to physic and physicians". ${ }^{26}$ In short, Forrest accused Brown of being nothing but an "empiric". The title "empiric" was a very useful term of abuse for one physician to throw at another with whom he was in dispute. But it should not be dismissed by us merely as a convenient insult. For it gets its abusive value from the fact that it has a precise meaning when deployed by a conventional, establishment, physician. An empiric is someone who sells a panacea or universal cure: a single pill or treatment for all (or many) diseases. In the view of the orthodox physician, the empiric has generalized erroneously from a few particular recoveries he had witnessed; confusing cause and effect, he has concluded that he possesses a universal cure. It was in this sense that Forrest condemned Brown as an empiric, who had brought dishonour on physic and physicians.

In a number of ways Brown's behaviour did indeed fit that of the typical empiric. In the first place there was the way in which his book had been circulated. Forrest (an Englishman) was familiar with the empirics in London putting up their advertisements on posts and walls; but here in Edinburgh, he concluded, the custom seemed to be for empirics to use a different form of self-advertisement: for he had first come across Brown's book as it was being hawked around the coffee-houses. Second, Brown had published his book in English: "Sure I am", Forrest wrote, "the publishing of physical books in our mother tongue does much hurt but no good: for thereby gardeners, old wives \&c. acquire as much knowledge as to kill, but seldom as to heal. In a word, as our proverb speaks, it is the putting a weapon in a mad-man's hands". ${ }^{27}$ Forrest - writing in English here too - felt he had to apologize for his own barbarous language, for he was being compelled to use "terms of art" in a context to which they were not appropriate: for the working terms, the technical terms, of medicine, should only be used in the working, international technical language, namely Latin.

In the third place Brown was claiming that there was a single cause (suppressed insensible perspiration) and a single cure (purging) for all patients suffering from any form of continued fever. For Brown had gone even further than Sydenham himself had done in print: Brown claimed that the purging method could be used in all cases of continued fever at all times - the therapy was not limited to the "constitution" of the atmosphere prevailing in 1685 , when the fever that Sydenham had described had first

${ }^{26}$ Brief defence, p. 145.

${ }^{27}$ Ibid., p. 147. 
broken out. To Forrest this concept of a single cause and a single treatment was typical of an empiric, and was totally erroneous because it ignored the real distinctions between diseases and between patients. It completely side-stepped the central activities of medicine: identifying the disease, understanding causation properly, judging the likely course of the disease, assessing the appropriate treatment, and fitting it to the circumstances of the patient under cure. These were all precision skills; the empiric by contrast used a sledge-hammer to repair a watch. "Not a few there be", Forrest wrote, "aiming more at their own profit than their neighbours' safety, who as they find it most easy, so they think it most safe, to acquire in some few years, I had almost said months, some general compend [= compendium] and universal method of curing, which they ignorantly and dangerously apply to all distempers." 28 Finally, it is the mark of the empiric to defend his claims by reference to his "successful experience". But such vaunted experience was inadmissible as evidence for someone like Forrest because it quite simply ignored the canons of logic, it made false connexions between cause and effect. This sort of experience was the antithesis of rationality in medicine - i.e. the use of reason and logic properly to interpret the teachings of experience. On every one of these counts Brown looked like an empiric, dishonouring the calling of the physician. Hence the "new" treatment represented to Forrest an attack on "Learning it self". ${ }^{29}$

The assault on Sydenham's method - as that method had been introduced to Edinburgh by Andrew Brown - thus cannot be reduced merely to the level of a conflict between personalities, nor can it be dismissed as mere perversity. Brown really seemed to be exhibiting the behaviour of an empiric, and it was just this sort of ignorant and dangerous practice that the new Royal College of Physicians was designed to stamp out. Brown's possession of an Aberdeen degree unfortunately put him beyond the College's jurisdiction, but it had not turned him into an acceptable practitioner.

The Newtonian dimension was introduced into the dispute by Archibald Pitcairne. He had been the figure behind "Dr. Black's" attacks on Brown from 1691, and may have prompted Forrest to publish in 1694. But it was not until the end of 1694 that Pitcairne made any contribution under his own name; nor, until that date, was any Newtonian element introduced into the fevers issue. To that time Pitcairne and his friends had been criticizing Brown's position rather than putting forward any alternative: the introduction of the Sydenham method to Edinburgh had not led the physicians there to make a serious reconsideration of their view of fevers. Brown had been trying to persuade them to change their views; but they believed they had long been practising a superior alternative to the new method. The "Newtonian" view, when Pitcairne at last put it forward, was not presented as a further novel way of treating fevers in response to a perceived challenge from the Sydenham approach. Rather it was a reformulation of the theory of fevers - explaining in fact why the "old" method worked so well. This is typical of Pitcairne's "Newtonian" medicine: it was aimed at revolutionizing medical theory, not primarily at producing new therapies.

28 Ibid., p. 23.

29 Ibid., p. 7. 


\section{Andrew Cunningham}

Pitcairne's conversion to Newtonian principles and his application of them to medicine had developed quite independently of the fever dispute. The son of an Edinburgh merchant branch of a landed family, Pitcairne took his medical degree in Rheims in 1680 after study at Paris. On returning to Edinburgh he became one of the charter fellows of the RCPE in 1681. The date of his initial conversion to a highly mathematics-oriented understanding of physiology cannot be established with certainty. But evidence from 1683 shows him already confident enough to issue mathematical challenges; and in the same year he also became acquainted with Bellini's most recent quasi-mathematical medical writings. 1687-88 was certainly the period when Pitcairne was converted to a specifically Newtonian approach: his friend David Gregory, professor of mathematics at Edinburgh university, introduced him to Newton's new Principia. Almost immediately Pitcairne turned to creating a "Newtonian" medicine, consulting Gregory on the calculations. ${ }^{30}$

When the revolution of 1689 occurred, Pitcairne, as a supporter of the rights of King James, was revealed to be (to use the new term) a Jacobite. For the rest of his life he was confronted by a "constitutional monarchy" of which he could not approve; he remained staunchly loyal to the Jacobite cause. The sort of difficulty faced by officeholders of Jacobite persuasions is exemplified by the fate of Pitcairne's friend, David Gregory, who in 1689 was obliged to leave his Edinburgh post as professor of mathematics because of his refusal to swear the oath of allegiance to the new monarchs. At about the same time, Pitcairne heard of the death of Lord Creichton under the usurping care of Andrew Brown - the whig. As a censor of the RCPE in 1690 , Pitcairne had a duty to root out such malpractice. Brown was thus an enemy to be pursued for medical, professional, and also political reasons. Brown could well afford to display his loyalty to the new regime in his contributions to the fever dispute which ensued; but Pitcairne and his friends simply did not dare to pick up this gauntlet. Their attacks on Brown, therefore, steer clear of any overt political comment.

Pitcairne's work on developing a "Newtonian" medicine received its first reward when, in September 1691, the Curators of Leyden University wrote via Lord Stair (who had recently been living in Leyden), inviting Pitcairne to come and accept the professorship of the practice of medicine. As Pitcairne had not yet published anything on medicine, he had presumably come to the Curators' notice on the basis of draft essays circulating in manuscript. Pitcairne accepted the post. By the time that he left Edinburgh, four items had been published in the fever dispute (two on each side). In March 1692, en route to Leyden, Pitcairne visited his hero, Newton, in Cambridge. ${ }^{31}$ The next month he was in Leyden, and on 26 April he delivered his inaugural oration; it was immediately printed, and copies quickly reached Edinburgh. From April 1692 until some time in the summer of 1693 Pitcairne taught at Leyden, making a great stir with his radical ideas.

Just as Newton's own Principia was largely inspired by a desire to correct the fallacies of Descartes' physics, so Pitcairne's medical writings were largely concerned

\footnotetext{
${ }^{30}$ See Christine M. Eagles, 'The mathematical work of David Gregory', Edinburgh University unpublished Ph.D. thesis, 1977, pp. 17-21.

${ }^{31} \mathrm{H}$. W. Turnbull (editor), The correspondence of Isaac Newton; Cambridge University Press, 1961, vol. 3, pp. 205-214. Pitcairne stayed only a couple of days.
} 


\section{Sydenham versus Newton: the Edinburgh fever dispute of the 1690s}

with doing the same for Descartes' physiology. Pitcairne's inaugural Oratio was a frontal assault on Cartesian physiologists and, to a lesser extent, on those who believed in "ferments" and the like. ${ }^{32}$ Following Newton's dictum that the natural philosopher should (unlike Descartes) work from the motions to discover the forces, and from the forces to derive the laws, Pitcairne asserted that "the business of a physician is to weigh and consider the powers (vires) of medicines and diseases as far as they are discoverable by their operations, and to reduce them to laws". The bodies which constitute the human frame are subject to the same laws as astronomers have discovered operate between the heavenly bodies. Therefore the practice (institutum) of the astronomers is to be followed: assembling observations made at different times and places, and thence computing the powers and forces which bodies in motion show in their behaviour toward other bodies. "From whence it follows that the laws and properties (affectiones) of the fluids and canals of human bodies may be defined after we shall have made more observations, or compared and methodized those that have already been made". What was inadmissible was the invention of "poetical machinery" like the Cartesians did - specially-shaped particles which exactly matched certain orifices in the glands. It was this sort of philosophical presupposition from which medicine needed to be freed.

When Andrew Brown in Edinburgh read this oration in 1692, he was quite unimpressed. He called Pitcairne "that fool Arche, that mere pageant of learning, who being one of the authors of that learned Dialogue written against Dr. Brown, thought to escape his reward because he was sheltered in a Chair; yet the impudent pretender declaiming, or rather belching from his Chair his foppery and impertinency, has so well chastized himself, that no body needs to be further solicitous to take any other correction of him, than by publishing to the world his inaugural oration, with some natural and pertinent remarks thereupon". ${ }^{33}$ Secure in his own confidence in Sydenham, and unable to comprehend the concepts Pitcairne was dealing in, Brown refused to be overawed by his main opponent's academic eminence.

In early 1693 at Leyden, Pitcairne continued his assault on Cartesian physiology. Besides giving lectures, he wrote four show dissertations (exercitii gratia) which were delivered by his Scottish and Dutch pupils - who had to defend publicly certain corollaries from them. All were immediately printed. ${ }^{34}$ Following on from the oration, these constituted a progressive, chapter by chapter, demolition of Cartesian explanations and their replacement by what Pitcairne believed to be Newtonian ones. (The fever paper of 1694-95 was to be the next in this cumulative sequence.) The central tenet of Pitcairne's approach was that the circulation of the blood is the paramount physiological activity, deriving of course from the force of the heart. On this

\footnotetext{
${ }^{32}$ Oratio, qua ostenditur medicinam ab omni philosophorum secta esse liberam, Habita LugduniBatavorum Die 26 Aprilis MDCXCII, Leyden, Elzevier, 1692. I have modified the translation by G. Sewell and J. T. Desaguiliers in The works of $\operatorname{Dr} A$. Pitcairn, London, Curll, 1715.

${ }^{33}$ See Appendix, no. 5, pp. 9-10. "Arche" is a pun on "Philarchus"; see note 24 above.

34 (i) Dissertatio de motu sanguinis per vasa minima, 17 January 1693.

(ii) Dissertatio de caussis diversae molis qua fluit sanguis per pulmonem natis et non natis, 1 April 1693.

(iii) Dissertatio de motu quo cibi in ventriculo rediguntur ad formam sanguini reficiendo idoneam. 18 April 1693.

(iv) Dissertatio de circulatione sanguinis in animalibus genitis et non genitis, 6 June 1693.
} 


\section{Andrew Cunningham}

everything else depends: health consists in proper secretion out of the freely circulating blood. The key to understanding physiology is therefore an appreciation of the hydraulics of the blood system. Pitcairne could therefore dismiss as a chimera the Cartesian apparatus of specially-shaped particles and sieves. He could also demonstrate his own alternative view: that the various quantities of the different evacuations of the body depend solely on the ratio of the number of excretory ducts to their respective cross-sections. Hence, "upon the increase of one evacuation, another is sometimes diminished". He came up with radical accounts of respiration and digestion: respiration serves not to absorb air into the blood, but to reduce the blood particles to spheres of the correct size for the circular mouths of the secreting vessels; digestion separates ingested food into its component particles by the grinding action of the stomach and the muscles of the abdomen. Finally, he maintained that the fundamental cause of disease is obstruction of the smallest arteries; nerves, veins, and secretory glands are not the locus of obstruction - they only become compressed by the obstructed arteries. Everything derives from the circulation and the force of the heart: the mode of secretion, the relative evacuations, the action of respiration, the processes of digestion and nutrition, and the cause of disease. The impulse of the blood accomplishes all the operations necessary for life and health.

Pitcairne's new type of theory undermines every principle on which Cartesian physiology had been built. It did away with all the fictions of the Cartesian mechanistic explanation, and replaced them with postulates, derived from Newton's work, which were at once more simple and more certain. By publishing these dissertations in Leyden, one of the medical centres of the world, Pitcairne instantly became recognized as the leading and most inventive exponent of the most sophisticated form of mechanism yet known. He was an international thinker now, and he knew it. When he returned to Edinburgh in the summer of 1693 for a holiday, it was as a Leyden professor. Under pressure, it is rumoured, from his future wife, he decided not to return to Leyden but to stay in Edinburgh. But he continued to act as if he was still the celebrated international professor, propagating his novel views with great arrogance, building a coterie of young disciples, and behaving as if he expected the intellectual leadership of the RCPE to be made over to him. He earned his living by returning to medical practice and, most probably, by taking paying pupils.

When Pitcairne began in 1688 to develop his Newtonian physiology, he was - like virtually everyone else - a supporter of the Stuart monarchy. The fact that he was amongst those who continued to adhere to this position after 1689 made him thereafter a "Jacobite", and he was a particularly vigorous and persistent defender of this position. The key to this set of principles lay (as Lenman has recently shown) ${ }^{35}$ not in the doctrine of the divine right of kings, but in the doctrine of indefeasible hereditary right. This right, of course, supported inheritance and succession among the ruling classes of Restoration England and Scotland, and it applied with even greater force to the monarchy: James VII and II had inherited his position as rightful monarch, and this right could not legally or morally be taken away from him. The doctrine of

\footnotetext{
${ }^{35}$ Bruce Lenman, The Jacobite risings in Britain, 1689-1746, London, Eyre Methuen, 1980, Chapter one, 'The prehistory of Jacobitism'; and see esp. p. 32.
} 


\section{Sydenham versus Newton: the Edinburgh fever dispute of the 1690s}

indefeasible hereditary right, obtaining throughout society, serves to promote stability by fixing the hierarchy of power. Deference is its counterpart, and (as Lenman writes), all citizens must ultimately, "through the great chain of human ranks, defer to the king, the supreme guarantor of deference and social order". So, with respect to the monarchy, the right - the power - to rule derives solely from heredity: and this right is not created by society in any way. Similarly, power radiates out from the monarchy; society depends on this source of power and energy, and stability is ensured by people obeying this authority, down through the social hierarchy.

In Pitcairne's account of the body natural the heart played a role closely analogous to that of the monarch in the body politic. On the beat of the heart absolutely everything depended: health (circulation and secretion); nutrition and growth; and finally, respiration. But we might even pursue the analogy further, to the question of the origin of the heart's sovereign force - the equivalent of the hereditary principle in monarchy. This question Pitcairne had indeed confronted in one of his Leyden dissertations. ${ }^{36} \mathrm{He}$ had argued there that all secretion is from the blood; before any secretion can take place, the blood must be circulating. In born creatures the heartbeat is maintained by the supply of "animal spirits" from the spinal marrow, previously secreted from the blood. But in the embryo this process is not yet possible. "Wherefore", Pitcairne concluded, "the powers of the heart and medullary substance had the same beginning, and act together; and by consequence no animal is ever produced mechanically. The fluid derived from the male brings with it an animal into the womb and ovaria of the female, which before enjoyed the circulation of the blood, and the benefit of life." The beat of the heart is in every sense prior to the mechanical functioning of the body. Similarly, for a Jacobite such as Pitcairne, the monarch's right to rule, established by heredity, is prior to the consent of his subjects.

While Pitcairne had been away in Leyden, the dispute over fevers had continued, with Brown publishing two further vehement defences of his new method. It may be that on his return Pitcairne approached James Forrest to write his Brief defence of the old and successful method, which was printed in 1694, and which has already been discussed. Forrest, it will be remembered, had chastized Brown for publishing in English, and for acting like an empiric in basing his claims for the validity of the new method on his "experience". Brown seems to have taken these lessons to heart. He turned the content of his Vindicatory schedule upside down, and put it into Latin. In this work, De febribus continuis tentamen theoretico-practicum (1695), Brown tried to represent the new method of Sydenham as growing from the mechanistic theory: thus the hypothesis is represented as being confirmed by the practice of purging. In other respects, as Brown acknowledged, the content is virtually the same as the Vindicatory schedule of 1691. So Brown had not been led to change his views by the technical criticism he had received. Instead, he was putting his unchanged views out in Latin - that is, for consideration by an international audience. Two interesting features of Brown's practice emerge from the Tentamen. First, he said that, as the smallest variations in the pulse of a febrile patient are important in the details of treatment, some means is required of remembering the patient's normal pulse; so

\footnotetext{
${ }^{36}$ See note 34 above, item iv.
} 


\section{Andrew Cunningham}

Brown normally adjusted the pendulum of a clock to coincide with the beats of the patient's normal pulse. ${ }^{37}$ Second, Brown had advocated (following Sydenham) that physicians should keep a detailed journal of their cases and the treatments they used. From his own journal he gave five detailed case-histories as an appendix to the book.

In the Tentamen Brown showed that he had not modified his views, despite the criticism levelled against them. Pitcairne felt it was time to enter the lists under his own name. At this period he had a serious illness and "could not walk without being supported", ${ }^{38}$ but by late September 1694 he had prepared a discourse De curatione febrium, quae per evacuationes instituitur. In sending manuscript copies of this to a London friend, Dr. Gray, he said "it is written only to lay the pride of some prattlers here". ${ }^{39}$

This dissertation was the sequential successor of Pitcairne's previous, Leyden, dissertations. Behind it lay the themes he had already established as central, notably the hydraulics of the circulation of the blood as the origin of secretion and evacuation. Though he had a radically new physiological theory, Pitcairne did not propose an equivalent radical interpretation of the course of fever. In fever it is observed that there is no perspiration, and the other evacuations are diminished; fevers arise from the suppression of evacuations. The natural or artificial cure of fevers is achieved through a crisis, when the evacuations are released: either copious urine, or a looseness of the bowels, or (most often) a sweat. As in each of his former dissertations, Pitcairne investigated only one problem here: "what kind of secretion or evacuation must be used in fevers, if any?" Questions such as what concoction consisted in, or when it was finished, were therefore not dealt with. Building on certain select observations (the method he had characterized as the practice of the astronomers) Pitcairne argued that the morbific matter in the blood can be drawn out by any of the critical evacuations in fevers:

\footnotetext{
We have said that it is observed that fevers go off by increasing the secretion through the skin, sometimes by increasing the secretion through the renal glands, or by causing a diarrhoea through the glands of the liver, of the pancreas, or the intestine.

Next we observe, that there are no secreting vessels, and no glands in our bodies serving for secretion, which cannot be increased to such a bulk, as to be able to receive and separate every fluid, even that which is naturally apt to be secreted in other glands. For we have noticed that in jaundice the gross liquor which is naturally secreted in the glands of the liver, is then secreted in the cuticular ones, and that the too great influx of saliva through its [proper] glands is stopped by causing the patient to sweat, and drawing off the salivary liquor by the cuticular glands; we see that a diarrhoea is stopped by turning the fluid into the passages of transpiration opened by sudorifics, and that a spitting cures a looseness. ... ${ }^{00}$.
}

The only question then remaining was to decide through which exit evacuation could be most efficiently made. Using the figures of Sanctorius for the ratios of the different evacuations in health, Pitcairne argued that "a greater quantity of morbific matter may, in a given time, be drawn off by a cuticular excretion, than by any other". The

${ }^{37}$ Tentamen, pp. 36-37.

${ }^{38}$ British Library, MS. Sloane 3198, f. 15: an undated gloss, in Pitcairne's handwriting, on some of his Latin poems.

${ }^{39}$ British Library, MS. Sloane 3216, ff. 164-166, letter from Pitcairne to Gray. 23 September 1694. Now printed in W. T. Johnston, The best of our owne: letters of Archibald Pitcairne, 1652-1713, Edinburgh, Saorsa Books, 1979, pp. 18-19.

${ }^{40}$ Appendix, no. 9; as translated in The works, 1715 (see note 32 above). 


\section{Sydenham versus Newton: the Edinburgh fever dispute of the 1690s}

relative effectiveness of the different evacuations was indeed so great that, Pitcairne said, "he that in one day in a state of health used to have ten stools, must when sick (if he would be cured by stool) have a thousand stools a day"! Pitcairne tried to establish the actual rate of what mathematics had proved to be the best form of evacuation in fevers, sweating; developing a theorem of Bellini's, he gave a mathematical demonstration of the weight of fluid discharged by a perspiration duct of a certain weight. Having proved his point, Pitcairne delivered two coups de grâce to Brown's views. He claimed that Brown's lenitive purges were not proper purges at all: they merely washed the perspiration filth off the surface of the intestines! Finally he used mathematics and hydraulics to show that an increased pulse-rate would always mean a greater velocity of blood-flow: "let those whose concern it is see how these phenomena of the pulses may be explained by a circulation of the blood slower than the natural, ascribed to fevers by several pretenders to physic".

As Pitcairne wrote in a letter to his friend Dr. Gray at London, ${ }^{41}$ some features of this dissertation were provisional. First, he was unhappy about Sanctorius' figures for the different evacuations in health. Second, he feared that his proof of Bellini's theorem might be vitiated by not having an authentic value for the weight of the man's skin (and hence of the weight of the perspiration ducts). The letter to Gray revealed other topics on which Pitcairne was currently working: the relation between the transmutation of curves and the method of healing; a theorem on the attractive forces of the parts of the blood; and a treatise on jaundice. On this last topic he wrote, "I have laid aside De ictero until we get some bodies to look into which are condemned to die. I want the measure of the capacity of some arteries, without which all is conjecture". The lack of bodies to dissect was also the reason why he had not weighed a man's skin for his fever dissertation; this particular uncertainty "shall be removed by the first dissection here". Pitcairne, continuing to develop his medical system in Edinburgh, though acting still as if he were a professor in Leyden, needed a supply of bodies to dissect; for his Newtonian approach to medicine stood on the twin supports of mathematics and an anatomy in which measurement was essential. So it was partly because Pitcairne was then writing on fevers, that he set out to obtain dissection facilities for himself in Edinburgh. Therefore, he applied (24 October 1694) to the Town Council for the right to have for dissection the bodies of those who died in the workhouse. As he wrote to his friend,

We offer to wait on those poor for nothing, bury them after dissection on our own charges (which now the town must do on theirs). And yet, Sir, there is vast opposition made to it by the chief-surgeons, who neither will eat hay, nor suffer the oxen to eat it. I do propose, if it be granted, to make better improvements in anatomy than have been made at Leyden these thirty years, for I think most or all anatomists have neglected or not known what was most useful for a physician.42

Indeed, the Surgeon-Apothecaries were so dismayed that they felt compelled to apply to the Town Council the very next week for a similar right to bodies for dissection. ${ }^{43}$

\footnotetext{
4 See note 39 above.

42 British Library, MS. Sloane 3216, f. 158, 24-25 October 1694. Printed in Johnston, op. cit., note 39 above, p. 19. The application was made through a surgeon friend, Alexander Monteith.

${ }^{43} \mathrm{H}$. Armet (editor), Extracts from the records of the Burgh of Edinburgh, 1689-1701, Edinburgh, The Corporation, 1962, p. 162.
} 


\section{Andrew Cunningham}

Within the RCPE its main founder, Sir Robert Sibbald, had constantly been trying to make the College serve a further function for its members; as a sort of medical equivalent in Edinburgh to the Royal Society of London. To this end he had repeatedly lobbied for the fellows to deliver monthly discourses on some topic. Pitcairne's turn was coming up in November. He had been planning to give a talk on scurvy, but when his turn to speak arrived (on November 1st) he chose to give his dissertation on fever instead. As the College minutes recorded the event: "Doctor Pitcairne having had (at Doctor Halyburton's desire) a Discourse De febribus the College was well satisfied therewith and returned to him the thanks of the board." 44 This minute, however, was mere form, for events were to show that half of the College was far from satisfied - they were outraged. Treating the discourse like one of his Leyden dissertations, Pitcairne immediately had it printed, as the next chapter of his medical odyssey, carefully mentioning on the title-page under whose auspices it had been given.

The RCPE was doomed to split on this issue. For Pitcairne found - what he had probably long suspected - that his views were not shared by most of his colleagues. The gifted lampoonist Dr. (Sir) Edward Eizat put out, anonymously, Apollo mathematicus, or the art of curing diseases by the mathematics (1695). One of Pitcairne's followers responded by unmasking the author. Very early within this new branch of the dispute, two of Pitcairne's own writings were republished in Edinburgh by his enemies old and new. First, there was a Latin reprint (1695) of his Leyden Oratio, a perfect text but with a helpfully offensive introduction and postscript; this is just what Andrew Brown had offered to issue in order to prove the stupidity of Pitcairne's views. Second, there appeared Apollo staticus, or the art of curing fevers by the mathematics, invented by Dr Pitcairne and published by him in Latine; now made English by a well-wisher to the mathematics (1695). This translation of the fever dissertation also included useful editorial hints:

\footnotetext{
More might be said to demonstrate the vanity of this man's pretensions, and the absurdity of this following Discourse; but the reading of it will supply that, and prove the best refutation of all. By what is here said anybody may see the vast difference that is between one that takes his observations from Nature, and one that takes his marks by the moon, that is, between a Rational and Mathematical Physician.
}

As a result of such publications, there ensued a "riot" and expulsions from the RCPE: the infant College was torn wide open. ${ }^{45}$ Two groups emerged, around Pitcairne and Sir Robert Sibbald respectively; their supporters were to slang each other for several years to come. The issue of the treatment of fevers had rebounded on the institution which had been established to defend the responsible practice of medicine in Edinburgh.

We have now followed the Edinburgh fever dispute through to the point where anarchy erupted in the RCPE; this we can treat as a convenient stopping-point, although it must be remembered that the treatment of fevers was to remain for some

4 Manuscript minutes. My thanks to the RCPE for permission to consult and cite these minutes.

45 W. B. Howie, 'Sir Archibald Stevenson, his ancestry, and the riot in the College of Physicians at Edinburgh', Med. Hist., 1967, 11 : 269-284. 


\section{Sydenham versus Newton: the Edinburgh fever dispute of the $1690 \mathrm{~s}$}

years a very live issue among the Edinburgh physicians. So, in conclusion, we can now look back briefly on the material presented here and turn it towards our initial historiographic question: why are different individuals attracted to - or "influenced by" - different ideas? The concept of "influence" has played an important part in writings on the history of medicine and science: for it has regularly been invoked to explain why a given individual believed " $x$ " or discovered " $y$ ". "Influence", then, has been used to give the cause of belief; it has been treated as an explanation in itself. But this explanation is something which itself demands to be explained. For we notice repeatedly that particular individuals take up particular beliefs (in this case medical beliefs), while others do not. How, then, does "influence" work?

I have reconstructed the present dispute on the premise that the ideas at issue did not have an autonomous existence: that they existed only insofar as individuals held them. Further, these individuals lived and operated within very particular contexts; and we can understand the adoption of a given idea only by looking very closely at the unique circumstances of the individual(s) by whom it was adopted. Obviously, for this purpose, a detailed reconstruction is essential. Thus, when looking at the "influence" of Newton's and Sydenham's ideas on Archibald Pitcairne and Andrew Brown respectively, I have attempted such a reconstruction - of Edinburgh medical practice, of Brown's and Pitcairne's individual biographies, their other activities, their medical status, and the like. This approach to understanding the circumstances within which "influence" operates has a counterpart in the position taken by a number of modern historians who have been trying to account for the origination of ideas. For they have similarly argued that ideas are not created by other ideas, but by individuals living and operating within very particular contexts, and that we can understand the origin and meaning of a given idea only by looking very closely at the unique circumstances of the individual who originated the idea.

There are two major assumptions with which I have worked. First, that what an individual assimilates in the course of his upbringing and formal education from parents, relatives, friends, teachers, and books does not require further explanation. The whole point of education is, after all, the presumption that people will believe what they are taught. So it is only when individuals show evidence of believing something other than what they were brought up to believe - when, that is, they step beyond their education - that we have a problem to explain. Second, I have assumed that there is a critical moment, a sort of conversion experience, which marks the change from an individual consciously believing one thing to believing another; for instance, between believing in the efficacy of traditional treatments and believing in the claims of Sydenham (the experience of Andrew Brown); between believing in Cartesian physiology and believing in Newtonian explanations (the experience of Archibald Pitcairne).

In order to explain why particular individuals in my case-study (and especially Brown and Pitcairne) were influenced by one "idea" and rejected the validity of the "idea" influencing their opponent, I have looked for a compatibility between their "influenced" approach to medicine and fever, and their views on other issues. The fact that the "Glorious Whig Revolution" occurred around the time of the fever dispute means that it is the political opinions of Brown and Pitcairne which are thrown into 


\section{Andrew Cunningham}

sharpest relief when we read the surviving evidence. I have, therefore, mainly concentrated on finding a compatibility between their respective political views and their medical views. In brief I have claimed that the sort of person who holds a patriotic, improving whig position is likely to find an experimental, empirical approach to medical treatment attractive; and the sort of person who holds a Jacobite political position is likely to embrace a physiological explanation which makes the heart dominant in all the functions of the body and which employs only a very limited number of fixed laws. (But what, beyond the circumstances of their upbringing, makes that sort of person "that sort of person" in the first place is something which we may never be able to uncover.)

But the contextualizing of medical ideas which I have attempted in this paper does not end here. For the dispute between Brown and Pitcairne was not only a dispute between an extreme Whig and a convinced Jacobite, it was also a battle between an "outsider" and an "insider" in the new arrangement of medical affairs in Edinburgh which had been recently instituted by the RCPE. It is hardly surprising, therefore, that they should have been at loggerheads: thus their different positions with regard to medical practice in Edinburgh are as important as their political beliefs in explaining their actions and medical commitments. What is more, the specific ideas and practices they adopted were intimately related to their earlier experiences. Pitcairne's particular theoretical education had predisposed him to mathematical medicine; Brown, who had learnt by doing, was far more ready to embrace the heretical and empiricallybased therapy of Sydenham.

This argument has a somewhat unexpected consequence. For, as a first stage in understanding what "influence" means, I turned it around from the passive to the active: to "be influenced" is to have the experience of conversion. But, as a second stage, we need to ask: what would such a conversion consist in? Surely it must involve the replacement of one set of beliefs by another, in the mind of a given individual. Yet, if individuals change their ideas in the ways I have been suggesting, it follows that no radical conversion ever actually takes place! (It may feel like that to the person involved - but that is a different thing.) For I have been arguing that individuals are in a sense "primed" for the reception of particular novel ideas, and they are "primed" not in a simple way, but through all the complexities of their life-history to that date. So ideas (be they scientific, medical, political, or whatever) are adopted not because of their intrinsic rightness but because of their appropriateness to the person adopting them. Similarly it follows that the preaching of new beliefs will be successful only if it is made to the provisionally converted.

When "influence" is looked at closely, it thus dissolves into a coherent and integral moment in the life-history of an individual. As the term "influence" as an explanation of anything therefore seems to have no substantive content, it is probably redundant. ${ }^{46}$ Each case is different, because each case involves an individual; and each person's set

\footnotetext{
${ }^{46}$ The best general consideration of the transfer of ideas is R. G. A. Dolby, 'The transmission of science', Hist. Sci., 1977, 15: 1-43; he does not, however, explore the mechanics of "influence". Quentin Skinner, in 'The limits of historical explanations', Philosophy', 1966, 41: 199-215, has an interesting discussion on the conditions under which "influence" can be evaluated to the level of a historical "cause"; but, again, he does not grapple with the content of the term "influence" itself.
} 
of ideas is different, because each person lives his own life: so the moment of adoption (or rejection) of novel ideas in each individual is different in its nature, because each of them brings to the event his own life-history, his own unique experience of the world in which he finds himself.

\section{APPENDIX: THE PAMPHLETS DISCUSSED IN THE PAPER}

The locations of copies consulted: BL British Library, London

NLS National Library of Scotland, Edinburgh

EUL Edinburgh University Library

RCPE Royal College of Physicians of Edinburgh

1. Andrew Brown, $A$ vindicatory schedule; concerning the new cure of fevers: containing a disquisition theoretical and practical, of the new and most effectual method of cureing continual fevers, first invented and delivered, by the sagacious Dr. Tho. Sydenham. Also shewing, by way of preliminary, the indispensible charge lyeing on physicians, to improve themselves, and the art. with the reasons why many palpable improvements in medicine, make so little progress. Where a new hypothesis of fevers, for establishing this method, is laid down, and several phaenomena are clearly resolved, applyed, and brought home to the confirmation thereof. With an appendix of Sanctorius his Medicina Statica, for clearing the doctrine of insensible perspiration, whereupon that hypothesis is founded. By Andrew Broun, M.D., Edinburgh, printed by John Reid, sold by John Mackie, 1691 [probably in May].

Copies at BL and NLS, which vary slightly.

Other editions: (i) London, 1696, printed for Walter Kettilby. (Found listed in an advertisement, but no copy located.) (ii) London, 1700, John Hepburn. Copies at Bodleian (Oxford) and Hunterian Library (Glasgow) - not seen.

2. "Dr. Black" [= Archibald Pitcairne and others?], A Survey of the Vindicatory Schedule in a dialogue betwixt Dr. Black and Dr. Brown. With an account of My Lord Creichtoun's case. [Edinburgh: no publisher]. Printed in the Year 1691. "Licensed Dec. 18 1691" (no licensing authority named).

Copies: BL and RCPE.

3. "Philander" [= Andrew Brown], A letter written to a friend in the countrey, concerning Dr. Broun's Vindicatory Schedule; and the dialogue written by some of the physicians in Edinburgh, in answer thereunto, Edinburgh [? Vallange], (January 15) 1692.

\section{Copy: NLS}

4. "Dr. Black" [= Archibald Pitcairne and others?], [An answer to Dr. Brown's Letter. . .J, Edinburgh, Mosman, 1692.

Referred to in number 5 below; no copy of it could be traced. 
5. "Philander" [= Andrew Brown], In speculo teipso contemplare Dr. Black. A looking-glass for the blackband of doctors. Wherein may be seen the ignorance and malice of these physicians, who have clubbed together under the name of Dr. Black, for suppressing by their scriblings, and other calumnies, so great a benefite to the world, as the new cure of fevers. Contained in a $2 d$. letter written by Philander to his friend in the countrey Philomathes. In defence of Dr. Broun, Edinburgh, printed by the Heir of Andrew Anderson, 1692.

Copies: BL and NLS.

5a. ["Dr. Black"], [Another pamphlet?], [1692].

6. "Philander" [= Andrew Brown], A third letter written by Philander to his friend in the countrey Philomathes, in vindication of Dr. Broun, and the new cure of fevers promoted by him, against the cavills and scruples that some yet intertain against it, [Edinburgh,? Heir of Anderson. 1692].

Copy: NLS

7. James Forrest, $A$ brief defence of the old and successful method of curing continual fevers; in opposition to Doctor Brown and his Vindicatory Schedule, Edinburgh, printed by George Mosman, and sold at his shop. 1694.

Copy: EUL; the RCPE copy is mislaid.

8. Andrew Brown, De febribus continuis Tentamen theoretico-practicum. Seu nova febrium hypothesis mechanica audacta ex principiis Bellini constructa, Edinburgh, Watson, 1695.

Copies: NLS and EUL.

9. Archibald Pitcairne, Dissertatio de curatione febrium quae per evacuationes instituitur. Lecta coram Collegio Medicorum Edinburgensium I Nov. 1694, [Edinburgh], Mosman, 1695.

Copy: BL

10. "Archibald Pitcairne", Oratio, qua ostenditur medicinam ab omni philosophorum secta esse liberam. Editio altera priore castigatior, [Edinburgh], 1695.

A reprint of the Leyden 1692 edition, but published by someone hostile to Pitcairne (possibly Andrew Brown), with a special preface and postcript.

Copy: NLS.

11. [Sir Edward Eizat], Apollo mathematicus: or the art of curing diseases by the mathematics, according to the principles of Dr. Pitcairn. A work both profitable and pleasant; and never published in English before. To which is subjoined a Discourse of certainty, according to the principles of the same author, [Edinburgh], 1695.

Copies: BL, NLS, etc.

12. "Archibald Pitcairne", Apollo staticus, or the art of curing fevers by the statics, invented by Dr. Pitcairn and published by him in Latine; now made English by a well-wisher to the mathematics, Edinburgh, J. W., sold by J. Wardlaw, 1695. A translation of number 9 , but published by someone hostile to Pitcairne, possibly Eizat or Brown.

Copy: NLS. 